\title{
Iconismo y narratario competente en El nombre de la Rosa
}

\author{
Iconism and competent narratee The Name of the Rose
}

\author{
Isabel Leal F. \\ Universidad del Bío-Bío, Facultad de Arquitectura, Construcción y Diseño, \\ Departamento de Artes y Tecnologías del Diseño, Concepción, Chile. \\ Correo electrónico: ileal@ubiobio.cl
}

\begin{abstract}
El presente artículo postula que Umberto Eco demuestra, por medio de la descripción novelesca del mundo icónico del medievo y la presencia de un narratario competente, su concepción teórica de la iconicidad como signo cultural y temporal basada en la convención. Para ello, aquí se analizan comparativamente dos capítulos pertinentes y significativos de su obra: "Primer día. SEXTA”, de su novela El Nombre de la Rosa, y "3.5. Critica del iconismo", de su Tratado de semiótica general.
\end{abstract}

Palabras clave: narratario, narrador, descripción, iconicidad, imagen.

This article suggests that Umberto Eco demonstrates, by means of the iconic fictional medieval world description and the presence of a competent narratee, theoretical conception of iconicity as cultural and temporal sign based convention. To that degree, there are two chapters which analyze the relevant comparative significance of his work: "First Day. SIXTH" from his novel The Name of the Rose, and "3.5. Critique of iconism "from his A Theory of Semiotics.

Key words: narratee, narrator, description, iconicity, image

\section{INTRODUCCIÓN}

No tendrás dioses ajenos delante de mí. No harás para ti escultura, ni imagen alguna de cosa que está arriba en los cielos, ni abajo en la tierra, ni en las aguas debajo de la tierra. No te inclinarás a ellas, ni las servirás, porque yo soy Jehová tu Dios, fuerte, celoso, que visito la maldad de los padres sobre los hijos hasta la tercera y cuarta generación de los que me aborrecen, y que hago misericordia a millares de los que me aman y guardan mis mandamientos (Ex. 20, 1-17).

La descripción se define habitualmente como representación de la realidad con palabras, pero también podemos verla precisada como pintura verbal, analogía que puede sustentarse en la idea de que el tiempo en la narración descriptiva se detiene para observar los detalles de un objeto, una persona o un entorno, como si de una 
pintura se tratara. Así, podemos decir que la descripción verbal es un proceso que va de la realidad -o de la percepción de una realidad tangible, imaginaria o supuesta- a la abstracción total de la palabra, cuyo resultado es una imagen recreada mentalmente por el lector. Atendiendo a esta idea, la diferencia con la imagen icónica no radica en la fuente que la genera -en ambos casos, realidad percibida tangible o imaginada- ni tampoco en su expresión, una verbal y otra visual, porque aunque distintas, divergen en su consecuencia. El resultante de la verbal es la abstracción de la palabra a la imagen mental y de ahí a una posible representación visual, en cambio, lo que resulta de la imagen icónica es otra realidad sintetizada, organizada e interpretada, cuya forma, al conservar en alguna medida ciertos grados de semejanza con la realidad percibida, produce un objeto capaz de incorporarse nuevamente al mundo tangible, construido e interpretable, y por lo tanto, un artículo potencialmente cambiado a palabra. Ambos procesos parecen similares, sin embargo, requieren competencias distintas.

La lectura de las imágenes nos parece un acontecimiento cotidiano, simple, empero le exige al lector relacionar y negociar constantemente las similitudes de su entorno perceptivo e imaginado con las representaciones bi o tridimensionales que de ella se hacen; son estas similitudes las que Umberto Eco aborda en el Tratado de Semiótica General (1995), estableciendo que se presentan dos límites en la concepción de icono; primero, un umbral que lo limita en sus relaciones de similitud y semejanza en relación al objeto de referencia; y segundo, en el otro extremo, una serie de códigos arbitrarios que hacen parecer que cualquier cosa puede ser ícono. La similitud y la abstracción del lenguaje en función de describir la imagen icónica es expuesto en El nombre de la rosa por medio de descripciones tan complejas en sus detalles que retan el conocimiento enciclopédico del lector, quien, para participar en el juego de lectura, debe construir una imagen mental que guarde cierto grado de coherencia y credibilidad con cualquier obra vivenciada y cuyas características se asemejen al icono descrito.

Para llevar a cabo esto, el autor realiza a lo menos dos acciones que son posibles de detectar: una estudiada selección de las imágenes icónicas de la Edad Media, todas ellas basadas en sus estados más representativos de dimensiones, materiales, estilos, texturas, formas, etc., y la reconstrucción -re-presentación- de una imagen que ha sido el resultado de un compendio de muchas obras pictóricas, escultóricas y arquitectónicas conocidas. Hablamos de la descripción de un objeto ficticio que debe motivar, por medio de referentes conocidos, una imagen mental creíble. Para que esto suceda, es necesario que el narrador se dirija a un tipo de lector con la competencia necesaria para entender el arte, estructura social, política, religiosa y cultural de la Edad Media, reconstruir su atmósfera y así, guiado por su sensibilidad para captar los detalles entregados por el texto, obtener, finalmente, una apreciación estética, sensorial y emotiva de lo narrado, así como de la obra total.

Todo esto conduce a varios cuestionamientos sobre el proceso. Las preguntas que aparecen son: ¿Cómo se entenderían las etapas de este proceso de codificación y decodificación, que incluye distintos actores, dentro de la semiosis? ¿A quién se dirige finalmente el narrador? ¿Qué condiciones exige el narrador para decodificar su mensaje? Y, por último, ¿participa el iconismo en este proceso? En relación a estas preguntas, mi hipótesis es que en la novela El Nombre de la Rosa de Umberto Eco (1989) existen descripciones que traspasan distintos niveles de textualidad -el verbal y el icónico-, generando un marco de referencia que, finalmente, construye lo que se podría denominar Imágenes de la Edad Media. Estas señales que emite el texto 
descriptivo no van dirigidas directamente al lector, sino que a un tipo de destinatario -narratario- que posee las competencias necesarias para decodificarlas y generar las formas icónicas adecuadas para imaginar el entorno narrado.

\section{LA REPRODUCCIÓN COMO DESCRIPCIÓN VERBAL Y PICTÓRICA}

La visión panorámica le permite al hombre apoderarse de lo exterior a distancia, percibir el espacio, las formas y colores de las cosas, distinguir y diferenciar. Estos elementos percibidos son referencias cuyo potencial es convertirse en conceptos que permitirán su re-producción convertidos en signos, en algún tipo de lenguaje. Cada persona tiene su propia forma de observar el mundo y la descripción nos da cuenta de ello. La descripción nos conduce a un objeto, sujeto o situación observada que induce a entenderla de una forma particular, pretende reproducir ciertas sensaciones por medio de artificios que, en el caso de este estudio, se remiten al artificio verbal o pictórico.

La definición informal de la descripción como una pintura verbal no es arbitraria, porque, al comparar las reproducciones pictóricas y verbales se pueden distinguir dos semejanzas que parecen claves: la temporalidad y el uso de figuras retóricas. En el primer caso, la idea del tiempo que se detiene es similar a la sensación del observador o pintor de una obra, quien se retrae del mundo para explorar en detalle lo que está concentrado en visualizar. Y en el segundo aspecto, el uso de metáforas, sinécdoques, hipérboles u otras estrategias, es análogo a la obra visual, que suele usarlas para enfatizar, persuadir o hacer reflexionar al lector sobre algunos aspectos de interés en ella.

Una buena descripción verbal permite que el lector no sólo ambiente la trama, sino que, además, le dé vida y forma a los personajes, es un descanso que le permite imaginar el entorno, elementos, época, olores, sabores y colores que le ofrece el texto. Frente a una descripción, el lector recrea una imagen mental, es decir, pasa de la abstracción del lenguaje escrito a crear en su mente una realidad concreta. De esta manera puede traspasar nuevamente lo imaginado a palabras, sin embargo, existen descripciones en extremo complejas cuya composición, número de elementos descritos, materialidad, detalles estilísticos, personajes irreales o casi sin referencias del mundo percibido, generan un texto de tal envergadura que es casi imposible retenerlo como una totalidad en la mente del lector y dificultando en extremo su decodificación. Estas descripciones se convierten en complejas porque exigen conocimientos previos que no siempre se poseen, es decir, algunas competencias culturales carecen de información suficiente para lograr una reconstrucción mental de lo descrito verbalmente.

En El nombre de la rosa hay diversos ejemplos de lo complejo que puede resultar seguir los detalles descriptivos que el personaje realiza, especialmente cuando en el capítulo titulado: "Donde Adso admira la portada de la iglesia y Guillermo reencuentra a Ubertino da Casale” (1989: 52-56) se detalla la portada y el arco de entrada de la abadía, descripción que exige conocimientos e imaginación de parte del lector. Por ello, no parece que estas palabras estén dirigidas al lector -ni real, virtual o ideal-, sino que las descripciones que realiza Adso de Melk en cuanto narrador contiene tal especificidad en sus detalles que sugiere la intervención de un narratario competente en arte de la Edad Media. Este narratario se encuentra presente en todo el texto y es necesario definirlo con cierta precisión. 
Sabemos que el narratario es un sujeto activo en la narración, que funciona como el interlocutor del narrador y, para Prince, según lo citado por Carrasco (1982), se reconoce y clasifica a partir del grado cero, es decir, a partir del momento en que se construye sobre las bases entregadas por el texto en que se encuentra o por el tipo de relato que se comunica. Usando este criterio, existen narraciones que contienen las señales necesarias para construir un narratario determinado y otras que no. En aquellas en las que se puede reconocerlo y caracterizarlo, son reconocibles tres tipos: un narratario que está de acuerdo a su posición con respecto al narrador, otro de acuerdo a los personajes y el que está de acuerdo a la narración. En cualquiera de los tres, según Perdomo (2002), su función en los relatos es la relevancia que adquiere para lograr un conocimiento adecuado de la narración; es un complejo constructo que deja una estela y desata (y recepciona) el aspecto tridimensional en el espacio textual (personaje, tiempo y espacio), que adquiere los fragmentos aleatorios de información, concentra entropía y produce significados para diversas interpretaciones, preparando de esta manera la escena textual para su gran momento reflexivo. Su existencia emerge de una interrelación entre el enunciado y los elementos discursivos, permitiendo que su estudio se realice desde el enunciado o en el discurso en cuanto a enunciación, ya que debido a su función comunicativa y como resultado de la suma de estos enunciados, finalmente, se logra textualizar y dar forma a la huella que permite al lector establecer la correspondencia entre los elementos del discurso. Narrador y narratario se ubican en los márgenes internos del discurso, porque éste manipula -textualiza- sus relaciones correspondientes al nivel pragmático, como un intercambio y tránsito de enunciado en un acto de enunciación.

El proceso de significación, para Perdomo, depende del diálogo entre narrador y narratario, donde este último, sugerido como un clon del lector, recrea una huella -o se convierte en la huella- que por su pura presencia genera el proceso semiótico. Ella misma sugiere que para Chatman (1990) el narratario es el interlocutor del narrador no representado y representado respectivamente. Huella y signo, dos formas de entender este diálogo entre narrador y narratario como un acto semiótico donde ambos comparten códigos que no siempre están al alcance del lector, y debe ser así, porque el narratario contiene las capacidades y competencias que el narrador le otorga. Siguiendo esta idea, Adso de Melk, en El nombre de la rosa, imagina a este interlocutor como alguien capaz de comprender lo que se le está contando, y por sus complejas descripciones podemos pensar que le exige ser un sujeto no sólo competente en el Medievo donde él vive, sino que especialmente ser un conocedor de su arte. Se puede inferir que el destinatario que construye este monje podría ser un transcriptor, traductor o ilustrador de libros, un hermano como él, con lo cual se establecería como coherente con la trama narrada. Para Chatman, el narrador y el narratario tienen una relación simbiótica y de dependencia que, en este caso, se ejemplificaría.

Formalmente, el narrador puede marcar o no al narratario (Perdomo 2002), lo que establece dos tipos de discurso narrativo: con narratario no marcado, si el narrador no explicita el destinatario, tenemos un narratario implícito, y con narratario marcado o explícito, en que el narrador señala mediante algunas expresiones cuyo referente no puede determinarse sino en relación con los interlocutores y, además, una cierta configuración de hacia quién se dirige. Los narratarios explícitos se agrupan, a su vez, en dos subclases: extradiegéticos, aquellos no involucrados directamente en la diégesis, el que sólo escucha; y el intradiegético, aquel involucrado en el nivel diegético como sujeto real o virtual de acciones (en términos ya conocidos instaurados 
por Genette 1972). Sobre esta base, Prada (1989) declara que al primero podemos dividirlo, a su vez, en narratario-alocutario, narratario-destinatario y narratario retórico. El primero correspondería al receptor en quien el emisor explícito quiere mediante su relato influir decisivamente y manipular su interpretación hacia un determinado juicio de valor o axiológico, en resumen, es a quien el narrador cuenta la cadena de eventos para influir en su ánimo, revestido obviamente por la figura de un actor. El narratario implícito decodifica, por tanto, el discurso, reinterpretando a su vez la imagen o configuración que el narratario explícito le entrega a la narración, no hay narratario-alocutario que no sea configurado con mayor o menor precisión dentro del mismo discurso y que no tenga una incidencia, más o menos directa en la narración contada, pues si bien permanece al margen de los eventos contados por el narrador explícito, su juicio y su acción podrían tener repercusiones ya sea en la sanción o en el desarrollo futuro de la historia. Otro caso es el narratario retórico, es decir, cuando se explicita su presencia que se hace figura por el lector virtual, pero no altera el transcurso de los hechos; es el caso de la confesión en que, desde una situación ya superada, el narrador-personaje cuenta su vida a su narratario que sólo puede escuchar su relato.

Según esta clasificación, en el Nombre de la Rosa (Eco 1989), existiría un narratario explicito, extradiegético y retórico, que queda en evidencia en el momento que el narrador declara su texto como un acto testimonial. Los párrafos claves para su reconocimiento se pueden encontrar, en su mayoría, al inicio del libro:

Ya al final de mi vida de pecador, mientras, canoso y decrépito como el mundo, espero el momento de perderme en el abismo sin fondo de la divinidad desierta y silenciosa, (...) me dispongo a dejar constancia sobre este pergamino de los hechos asombrosos y terribles que me fue dado presenciar en mi juventud, repitiendo verbatim cuanto vi y oí, y sin aventurar interpretación alguna, para dejar, en cierto modo, a los que vengan después (si es que antes no llega el Anticristo) signos de signos, sobre los que pueda ejercerse la plegaria del desciframiento.

El señor me concede la gracia de dar fiel testimonio de los acontecimientos que se produjeron en la abadía cuyo nombre incluso conviene ahora cubrir con un piadoso manto de silencio, hacia finales del año 1327 (...).

Pues bien, es probable que haya dicho cosas incoherentes sobre fray Guillermo, como para registrar desde el principio la incongruencia de las impresiones que entonces me produjo. Quizá tú, buen lector, puedas descubrir mejor quién fue y qué hizo, reflexionando sobre su comportamiento durante los días que pasamos en la abadía. Tampoco te he prometido una descripción satisfactoria de lo que allí sucedió, sino sólo un registro de hechos (eso sí) asombrosos y terribles (Eco 1989: 22-23).

Al final, Adso explicita su disposición ante lo narrado, su posible lector, y, de forma muy sutil, la conexión entre obra y título:

(...) Pero esas páginas incompletas me han acompañado durante toda la vida que desde entonces me ha sido dado vivir, las he consultado a menudo como un oráculo, y tengo casi la impresión de que lo que he escrito en estos folios, y que ahora tú, lector desconocido, leerás, no es más que un centón, un carmen figurado, un inmenso acróstico que no dice ni repite otra cosa que lo que aquellos fragmentos me han sugerido, como tampoco sé ya si el que ha hablado hasta ahora he sido yo o, en cambio, han sido ellos los que han hablado por mi boca. 
(...) Me hundiré en la tiniebla divina, en un silencio mudo y en una unión inefable, y en ese hundimiento se perderá toda igualdad y toda desigualdad, y en ese abismo mi espíritu se perderá a sí mismo, y ya no conocerá lo igual ni lo desigual, ni ninguna otra cosa: y se olvidarán todas las diferencias, estaré en el fundamento simple, en el desierto silencioso donde nunca ha existido la diversidad, en la intimidad donde nadie se encuentra en su propio sitio. Caeré en la divinidad silenciosa y deshabitada donde no hay obra ni imagen.

Hace frío en el scriptorium, me duele el pulgar. Dejo este texto, no sé para quién, este texto, que ya no sé de qué habla: stat rosa pristina nomine, nomina nuda tenemus” (Eco 1989: 677-678; las cursivas son mías).

Tenemos entonces a un narrador que deja huellas, signos traducibles, claves que están pensadas para un narratario capaz de comprenderlas, que mediatiza sus experiencias a través del narratario; el lector es testigo, pero no puede participar de este diálogo narrador-narratario, aunque sólo en él cobra vida, se construye en su proceso semiótico.

\section{SOBRE LA ICONICIDAD}

La primera pregunta que surge es: ¿por qué hablar de iconicidad en el texto $E l$ Nombre de la Rosa si no se observan signos de este orden? Al leer el libro, salvo por algunos planos que el autor expone al inicio y cuya iconicidad es discutible, no aparecen imágenes que justifiquen el estudio de códigos icónicos, menos aún que permitan analizarlos. Sin embargo, el narrador realiza variadas descripciones de distintos referentes icónicos, que entregan atmósfera y ambientación al periodo y lugar en el que transcurren los eventos de la historia. La selección de las obras que se describen en el libro no es arbitraria, lo que se puede deducir porque son en extremo detalladas. Por otra parte, los comentarios realizados por el narrador de las formas y elementos que lo componen, permiten generar su perfil psicológico y emocional, como también elaborar una imagen mental del entorno de los eventos narrados.

Pero si somos capaces de generar una imagen mental leyendo un texto, ¿'estamos enfrentados a signos icónicos? ¿Qué es, entonces, un signo icónico? Es conveniente aclarar este punto. Umberto Eco, en el capítulo 3.5 del Tratado de semiótica general (1995), titulado “Crítica del iconismo”, realiza un análisis crítico de las nociones con que, según él, se ha explicado y entendido el signo icónico. Su posición sobre el signo icónico se basa en la convención y la cultura, rechazando aquellas ideas que llama ingenuas y que son las siguientes: a) Los signos icónicos tienen las mismas propiedades que el objeto; b) Los signos icónicos son semejantes al objeto; c) Los signos icónicos son análogos al objeto; d) Los signos icónicos son motivados por el objeto. Pero estas referencias basadas en la comparación de similitud existente entre signo y objeto tienen su extremo opuesto, que también cuestiona, y éstas son: a) Los signos icónicos están codificados arbitrariamente; b) Los llamados signos icónicos son analizables en unidades pertinentes y codificadas y permiten una articulación múltiple como los signos verbales.

Es interesante observar cómo Eco argumenta cada uno de estos puntos. La primera definición es la versión de Morris (1985), quien declara que el signo icónico tiene las mismas propiedades de lo denotado, versión que Eco, sin dejar de darle cierto crédito, considera confusa, puesto que si se considera el ejemplo del modelo de un retrato pictórico, no existen las mismas propiedades entre ambos, pintura y modelo. Este 
principio podría fundamentarse de alguna forma con el aporte de Moles (Vilches 1990), quien establece niveles de iconicidad, donde la diferencia entre niveles se establece por grados de semejanza existentes entre la representación icónica y el denotatum. Moles (Villafañe 2000) lo esquematiza en una escala de iconicidad decreciente de 12 niveles, en donde el nivel 12 es el objeto y el nivel 0 la abstracción de la palabra, número o cualquier otro símbolo abstracto. Este esquema nos aclara la distancia existente entre el nivel del "mundo real”, la representación pictórica y la descripción verbal. Mientras el texto escrito se encuentra en el último nivel de abstracción, en los niveles intermedios se encuentra la fotografía (9), el dibujo (8) y el esquema anatómico o de construcción (7). Pero si bien estos niveles pueden considerarse como escalas de semejanza, es necesario que se reflexione sobre este punto.

Incorporar la idea de semejanza produce un gran cambio, porque permite entender que un signo icónico no requiere las mismas propiedades físicas del objeto, pero estos sí deben estimular una estructura perceptiva “semejante” a la que estimularía el objeto imitado. Sin embargo, este concepto tampoco se ajusta con exactitud al iconismo que propone Eco, ya que los objetos motivan sensaciones muy variadas y muchas veces muy distintas a su representación visual. Tampoco acepta el término de semejanza propuesto por Pierce, quien expresa que un signo es icónico cuando puede representar a su objeto, sobre todo por semejanza (Eco 1995: 292-295). Para cuestionar esta versión, Eco se remite a la geometría y a las relaciones de isomorfismo, que demuestran la reducción a los criterios de medida y espacialidad establecidos por convención. La convención los hace variables a una determinada cultura, y por ello, no se puede hablar de un tipo de semejanza que no dependa del universo cultural de quien la establece.

En este punto, parece interesante relacionar su argumentación con la realizada por Foucault (1968), donde aborda el tema de la similitud. Éste, para hablar de ella, se remonta hasta el siglo XVI, donde reconoce cuatro tipos de similitud: convenientia, aemulatio, analogía y simpatía. Cada una de ellas expresa un tipo de relación de semejanza que va desde lo más hasta la menos evidente. Es así, entonces, que la convenientia está basada en la vecindad topológica, se relaciona con la espacialidad e indica un encadenamiento producido por la asimilación de lo cercano. La aemulatio es una similitud activa que ya no depende del lugar ni de la distancia, ya que es una relación de gemelidad natural, reflejos especulares entre sí, visibles y reconocibles por los observadores. En la tercera forma, la analogía, se superponen las dos anteriores, son similitudes que hablan del parentesco entre las cosas y van desde la multiplicación de sí misma a las relaciones comparativas realizadas por motivos diversos. Por último, la simpatía es una categoría de semejanza que no posee ningún camino trazado de antemano, en ella nada está pre-escrito ni se encadena, pero su poder es tan fuerte que aproxima no importando las distancias, asimila, mezcla y hace que las cosas pierdan su individualidad. Para reconocer estas similitudes deben existir marcas que entreguen la posibilidad de realizar estas relaciones; a ellas el autor las denomina signaturas y se caracterizan por ser visibles en su superficie, Eco los llama rasgos del contenido o elementos pertinentes (1995: 305). Esta reflexión de Foucault sobre las semejanzas da luces sobre la forma en que el ser humano ha generado un proceso lógico del pensar basado en la medida, numeración y el orden, lo que ha llevado a la epistemología del occidente a un dominio del razonamiento lógico y deductivo.

La forma en que Eco habla de isometría se relaciona también con las que proponen Wolf y Kuhn (1977), quienes hablan de distintos niveles de simetría, 
principios que Bonsiepe (1978) utiliza para definirlos como los siguientes: la simetría isométrica o axial es donde entre objeto y objeto existe igualdad de tamaño y forma, la simetría homeométrica donde existe igualdad de forma y distinto tamaño, la simetría singenométrica que habla de cambios graduales de la forma, la simetría catamétrica que son objetos que guardan relaciones de similitud entre la forma interfiguralmente -semejanzas entre forma y forma- e intrafiguralmente, semejanzas de una forma consigo misma. Por último, existen formas que sólo guardan similitud intrafiguralmente, pero no interfiguralmente, llamadas simetrías heterométricas. Desde luego, la taxonomía culmina con aquellas formas que no tienen similitud intrafigural ni interfigural, la llamada ametría, pero esta clasificación es sólo conceptual y no existe en la representación. Muchas de las relaciones de semejanza, al igual que las pertinencias, están principalmente basadas en la convención cultural más que en los rasgos observables por medio de estímulos sensoriales, argumento igualmente válido para considerar que los signos icónicos se sustentan en analogías.

Estos principios artístico-formales basados en la semejanza se hacen presentes en El Nombre de la Rosa cuando Adso menciona los conceptos de variedad en la unidad y de unidad en la variedad, o bien, cuando se concentra en la composición de la obra que observa. Pero no debemos pensar en la simetría como sinónimo de iconismo; en el Tratado..., Eco lo demuestra cuando se detiene en los reflejos especulares, los dobles y las reproducciones basados en ratio facilis y los llamados signos expresivos. Para él, los reflejos y los dobles no pueden ser considerados signos porque los primeros no están en lugar de otra cosa sino que frente a otra cosa, es decir, no existen en lugar de, sino a causa de la presencia de algo; cuando ese algo desaparece, lo mismo le sucede a la pseudoimagen del espejo. Igual ocurre con la fabricación o existencia de dobles que sólo podrían ser íconos cuando son un modelo, como en el caso específico del objeto usado como signo ostensivo, es decir, como objeto elegido por alguien para ser mostrado como un representante de la clase a la que pertenece. Tampoco son signos icónicos, por muy simétricas que parezcan, las reproducciones regidas por ratio facilis que conciernen a las categorías regidas por las semejanzas entre los rasgos típicos y los rasgos realizados; en primer lugar, porque los signos icónicos no prescriben el continuum material del que está hecho el espécimen originario y, en segundo, porque en el caso de los signos expresivos, son realizaciones de orden perceptivo y no icónico.

Con estos argumentos, Eco refuerza la idea que el carácter icónico de un signo está basado en la convención, por lo tanto, es cultural y temporal. Un ejemplo clásico que demuestra esta teoría es el rinoceronte de Durero, donde reproduce icónicamente al animal con placas y escamas y no con rugosidades de la piel, filtro cultural entendible por su época y cultura. En resumen, Eco declara entonces que re-presentar icónicamente un objeto significa transcribir mediante artificios gráficos -o de otra claselas propiedades culturales que se le atribuyen. La cultura, cuando define sus objetos, recurre a códigos de representación icónica, lo que implica reconocer los rasgos de contenido pertinentes de reconocimiento que el modelo debe aportar. Se dan entonces ciertos grados que van desde las representaciones icónicas más esquemáticas como el sol (círculo y líneas radiales) a representaciones icónicas más realistas, las que su vez se pueden dividir en los que se ven, de los que se sabe o ha aprendido a ver (como es el caso de una pintura figurativa o hiperrealista a otra cubista). Es así que el autor concluye que los rasgos del contenido de numerosas entidades culturales son de orden óptico, es decir, que dependen de experiencias perceptivas anteriores, ontológico, es 
decir, que conciernen a las propiedades perceptibles de hecho, pero que la cultura se las atribuye al objeto, y convencional, es decir, que depende de convenciones iconográficas que han caracterizado intentos anteriores de reproducciones ópticas.

En consecuencia, el código icónico será el sistema que hace corresponder a otro sistema de vehículos gráficos unidades perceptivas y culturales codificadas, o bien, unidades pertinentes de un sistema semántico que depende de una codificación precedente de la experiencia perceptiva. Umberto Eco considera que los llamados signos icónicos son textos visuales que no son analizables ulteriormente en signos ni en figuras y que, más que depender de un código, instituyen un código, más que signos, son modos de producción de funciones semióticas. Esto puede apreciarse en muchos casos donde la constitución de semejanza que se le atribuye al mal llamado signo icónico, aunque esté regida por convenciones, más que depender de hábitos culturales, parece estar regida por mecanismos perceptivos, pues en su límite se pueden observar textos que prometen una regla más que seguirla. El iconismo representa, en consecuencia, lo que Eco denomina una colección de fenómenos agrupados, si no al azar, por lo menos con gran largueza de ideas muy distintas entre sí. Es una correlación de texturas expresivas muy imprecisas y una porción de contenido vasta e imposible de analizar. Por todo esto, se puede decir que en El Nombre de la Rosa no aparecen signos icónicos, sin embargo, se habla de ellos, se los describe y resulta interesante atender al hecho que de alguna forma, por lo dicho anteriormente, las descripciones verbales nos conducen igualmente a una percepción icónica de la realidad.

\section{ANÁLISIS DEL TEXTO ICÓNICO Y DEL NARRATARIO}

La historia de El nombre de la rosa es una secuencia de intrigas provocadas por asesinatos que transcurren en una abadía; en este espacio virtual, sitúa el mundo cristiano de la Edad Media, abordado con sus virtudes y defectos. El espacio focal de la abadía es la biblioteca, de forma que el saber queda supeditado a la religión, lucha entre lo ontológico y la episteme, porque ella resguarda la mayor cantidad de libros registrados hasta el año 1327. Sus habitantes viven y trabajan para alimentar los volúmenes de su biblioteca, transcribiendo e iluminando páginas con miniaturas, traduciéndolas y copiándolas. Sus monjes no son sólo hombres dedicados a Dios, sino que también son hombres de estudio, caligrafistas de oficio o talentosos ilustradores; aparece el arte, la expresión estética, pero contrastada con la fealdad, en síntesis todo un mundo que requiere ser descrito. En la obra, el narrador describe prácticamente todo, pero al ser la biblioteca el centro, describe libros, ambientes, sus personajes y la misma arquitectura de la abadía y la biblioteca. Este estudio se basa en una de estas descripciones, específicamente la que se refiere a sobre relieves arquitectónicos o a imágenes que se encuentran ubicadas en las bases estructurales del edificio de la abadía, "Primer día, Sexta, Donde Adso admira la portada de la iglesia y Guillermo reencuentra a Ubertino da Casale” (1989: 52-59), concentrándose en la descripción del portal.

El título contextualiza el período y el entorno en que transcurre la historia, especificando la segmentación horaria (Sexta) que explica el autor al inicio del libro y que indica los rituales de la orden, se anticipa al contenido narrado y destaca el 
impacto que para el protagonista tiene la visión de la portada y sus formas. En el primer párrafo se describe la iglesia:

La iglesia no era majestuosa como otras que vi después en Estrasburgo, Chartres, Bamberg y París. Se parecía más bien a las que ya había visto en Italia, poco propensas a elevarse vertiginosamente hacia el cielo, sólidas y bien plantadas en la tierra, a menudo más anchas que altas, con la diferencia, en este caso, de que, como una fortaleza, la iglesia presentaba un primer piso de almenas cuadradas, por encima del cual se erguía una segunda construcción, que más que una torre era una segunda iglesia, igualmente sólida, calada por una serie de ventanas de línea severa, y cuyo techo terminaba en punta. Robusta iglesia abacial, como las que construían nuestros antiguos en Provenza y Languedoc, ajena a las audacias y al exceso de filigranas del estilo moderno, y a la que sólo en tiempos más recientes, creo, habían enriquecido, por encima del coro, con una aguja, audazmente dirigida hacia la cúpula celeste (1989: 52).

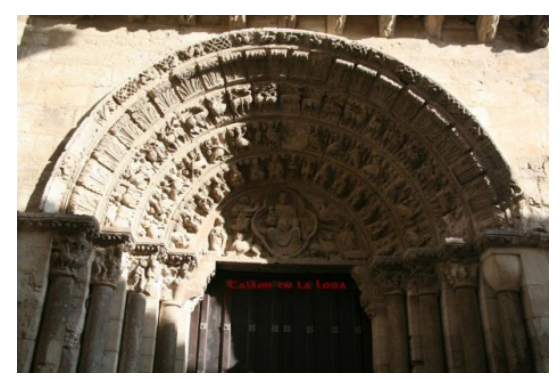

Ilustración No 1, Santa María de Tudela.

Esta comparación aclara que la iglesia que el narrador va a describir posee ciertas condiciones que la hacen diferente a otras en cuanto a su majestuosidad, por lo tanto, exige que el narratario sepa sobre las iglesias de Estrasburgo, Chartres, Bamberg y París, también sepa sobre las características estructurales de las iglesias de Italia, especialmente las de Provenza y Languedoc. En el anexo se puede observar que las iglesias llamadas majestuosas por el narrador son las que ya presentan estilo gótico, con sus torres más altas y con menos masa que las italianas que se ven más románicas con mayor masa y menos ventanas. El texto también exige un vocabulario semi-culto que le permita hacer referencia a términos arquitectónicos y estructurales, como almena o filigrana. Pese a esto, aún no se aprecian grandes problemas de decodificación.

En el segundo y tercer párrafo se realiza la descripción de la estructura arquitectónica y ambiental del tímpano.

Ante la entrada, que, a primera vista, parecía un solo gran arco, destacaban dos columnas rectas y pulidas de las que nacían dos alféizares, por encima de los cuales, a través de una multitud de arcos, la mirada penetraba, como en el corazón de un abismo, en la portada propiamente dicha, que se vislumbraba entre la sombra, dominada por un gran tímpano, flanqueado, a su vez, por dos pies rectos, y, en el centro, una pilastra esculpida que dividía la entrada en dos aberturas, defendidas por puertas de roble con refuerzos metálicos. 
En aquel momento del día el sol caía casi a pico sobre el techo, y la luz daba de sesgo en la fachada, sin iluminar el tímpano. De modo que, después de pasar entre las dos columnas, nos encontramos de golpe bajo la cúpula casi selvática de los arcos que nacían de la secuencia de columnas menores que reforzaban en forma escalonada los alféizares. Cuando por fin los ojos se habituaron a la penumbra, el mudo discurso de la piedra historiada, accesible, como tal, de forma inmediata a la vista y a la fantasía de cualquiera (porque pictura est laicorum literatura), me deslumbró de golpe sumergiéndome en una visión que aún hoy mi lengua apenas logra expresar (1989: 53).

Esta descripción nos remite a la Ilustración $N^{\circ} 1$, sin embargo, sólo menciona dos columnas y, observando variados referentes, es común observar más de dos. Se concentra en términos arquitectónicos algo más complejos como alféizares y tímpanos. Hasta el momento, el narrador ha contextualizado la atmósfera y el entorno arquitectónico del objeto que más adelante describirá. Para lograr su objetivo se detiene en la luz y la materialidad. El comentario en latín que significa «la pintura es la literatura de los legos», nos sugiere la conectividad entre la narración verbal e imagen, dirigida a distintos públicos con diferentes niveles de cultura donde ambas tienen importancia narrativa. Para ver qué tipo de referencias pueden haber provocado este texto es conveniente remitirse, aparte del expuesto por Eco en Apostillas al Nombre de la Rosa (Eco, 1989) -el Tímpano del portal principal de la basílica de Sainte-Madeleine en Vezelay (Borgoña)- a tres tipos de iglesias famosas del arte románico: Tímpano de la Iglesia de la Abadía de Santa Fe de Conques, la Iglesia abacial de Moissac, Gascuña (también con referencia en Apostillas ...) y la de Santa María Magdalena de Tudela.

En el cuarto párrafo se describe la figura y composición del Pantocrátor:

Vi un trono colocado en medio del cielo, y sobre el trono uno sentado. El rostro del Sentado era severo e impasible, los ojos, muy abiertos, lanzaban rayos sobre una humanidad cuya vida terrenal ya había concluido, el cabello y la barba caían majestuosos sobre el rostro y el pecho, como las aguas de un río, formando regueros todos del mismo caudal y divididos en dos partes simétricas. En la cabeza llevaba una corona cubierta de esmaltes y piedras preciosas, la túnica imperial, de color púrpura y ornada con encajes y bordados que formaban una rica filigrana de oro y plata, descendía en amplias volutas hasta las rodillas. Allí se apoyaba la mano izquierda, que sostenía un libro sellado, mientras que la derecha se elevaba en ademán no sé si de bendición o de amenaza. Iluminaba el rostro la tremenda belleza de un nimbo cruciforme y florido, y alrededor del trono y sobre la cabeza del Sentado vi brillar un arco iris de esmeralda. Delante del trono, a los pies del Sentado, fluía un mar de cristal, y alrededor del Sentado, en torno al trono y por encima del trono vi cuatro animales terribles. Terribles para mí que los miraba en éxtasis, pero dóciles y agradables para el Sentado, cuya alabanza cantaban sin descanso (1989: 54).

En este párrafo, y por las imágenes que podemos apreciar que corresponden a iglesias distintas, el gesto de Dios con un libro en la mano izquierda y la bendición en la mano derecha era común en el arte, aunque también se puede apreciar en otras imágenes ambos brazos extendidos con las palmas hacía a arriba. También las cuatro bestias que lo rodean es una temática recurrente. Estos seres eran generalmente cuatro animales, pero también se observan dos en el nivel inferior y dos ángeles en el espacio superior.

En el cuarto y quinto párrafo vemos la descripción de los seres que rodean a Dios: 
En realidad, no digo que todos fueran terribles, porque el hombre que a mi izquierda (a la derecha del Sentado) sostenía un libro me pareció lleno de gracia y belleza. En cambio, me pareció horrenda el águila que, por el lado opuesto, abría su pico, plumas erizadas dispuestas en forma de loriga, garras poderosas y grandes alas desplegadas. Y a los pies del Sentado, debajo de aquellas figuras, otras dos, un toro y un león, aferrando entre sus cascos y zarpas sendos libros, los cuerpos vueltos hacia afuera y las cabezas hacía el trono, lomos y cuellos retorcidos en una especie de ímpetu feroz, flancos palpitantes, tiesas las patas como de bestia que agoniza, fauces muy abiertas, colas enroscadas, retorcidas como sierpes, que terminaban en lenguas de fuego. Los dos alados, los dos coronados con nimbos, a pesar de su apariencia espantosa no eran criaturas del infierno, sino del cielo, y si parecían tremendos era porque rugían en adoración del Venidero que juzgaría a muertos y vivos.

En torno al trono, a ambos lados de los cuatro animales y a los pies del sentado, como vistos en transparencia bajo las aguas del mar de cristal, llenando casi todo el espacio visible, dispuestos según la estructura triangular del tímpano, primero siete más siete, después tres más tres y luego dos más dos, había veinticuatro ancianos junto al trono, sentados en veinticuatro tronos menores, vestidos con blancas túnicas y coronados de oro. Unos sostenían laúdes; otros, copas con perfumes; pero sólo uno tocaba, mientras los demás, en éxtasis, dirigían los rostros hacia el Sentado, cuya alabanza cantaban, los brazos y el torso vueltos también como en los animales, para poder ver todos al Sentado, aunque no en actitud animalesca, sino detenidos en movimientos de danza extática (...) de forma que, fuese cual fuese su posición, las pupilas, sin respetar la ley que imponía la postura de los cuerpos, convergiesen en el mismo punto de esplendente fulgor (1989: 55).

La representación de estas cuatro figuras que rodean a Dios, se encuentran en más de un portal de catedral en Europa y parecen representar, como lo dice Adso, seres de aspecto temible pero no demoníaco sino que celestial. La Edad Media está llena de formas confusas, en donde no necesariamente se da una relación irrestricta entre belleza y el bien, o entre la monstruosidad y la maldad, a veces se representa al mal con una cubierta de hermosura y el bien se puede encontrar en un aspecto de fealdad. Este discurso es coherente con el texto en donde, en un ambiente de calma y paz clerical, se encuentra el asesinato.

El simbolismo de los números, de la disposición, de la ubicación, de lo que cada uno tiene en sus manos y el gesto de cada participante, también es observado en muchos tímpanos de la época, en algunos las figuras se encuentran distribuidas como es descrito en el libro, pero otra disposición común era disponerlos en las columnas que rodeaban el portal. El significado de aquellos símbolos seguramente lo pueden conocer expertos en el arte del Medievo o personas cercanas al estudio iconográfico religioso.

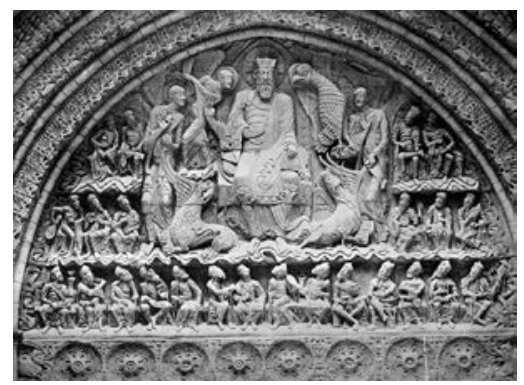

Ilustración $\mathrm{N}^{\mathrm{o}}$ 2. Iglesia de San Pedro de Moisacc. 


\section{Sexto y séptimo párrafo: descripción de los apóstoles y el ornamento vegetal}

¡Oh, qué armonía de entrega y de ímpetu, de posiciones forzadas y sin embargo llenas de gracia, en ese místico lenguaje de miembros milagrosamente liberados del peso de la materia corpórea, signada cantidad infundida de nueva forma sustancial, como si la santa muchedumbre se estremeciese arrastrada por un viento vigoroso, soplo de vida, frenesí de gozo, jubiloso aleluya prodigiosamente enmudecido para transformarse en imagen!

Cuerpos y brazos habitados por el Espíritu, iluminados por la revelación, sobrecogidos y cogidos por el estupor, miradas exaltadas por el entusiasmo, mejillas encendidas por el amor, pupilas dilatadas por la beatitud, uno fulminado por el asombro hecho goce y otro traspasado por el goce hecho asombro, transfigurado uno por la admiración y rejuvenecido otro por el deleite, y todos entonando, con la expresión de los rostros, con los pliegues de las túnicas, con el ademán y la tensión de los brazos (...). Y a los pies de los ancianos, curvados por encima de ellos, del trono y del grupo tetramorfo, dispuestos en bandas simétricas, apenas distinguibles entre sí, porque con tal sabiduría el arte los había combinado en armónica conjunción, iguales en la variedad y variados en la unidad, únicos en la diversidad y diversos en su perfecto ensamblaje, ajustadas sus partes con prodigiosa precisión y coloreadas con tonos delicados y agradables, milagro de concordia y consonancia de voces distintas entre sí, trama equilibrada que evocaba la disposición de las cuerdas en la cítara, continuo parentesco y confabulación de formas que, por su profunda fuerza interior, permitían expresar siempre lo mismo a través, precisamente, del juego alternante de las diferencias ornamento, reiteración y cotejo de criaturas irreductibles entre sí y sin cesar reducidas unas a otras, amorosa composición, efecto de una ley celeste y mundana al mismo tiempo (vínculo y nexo constante de paz, amor, virtud, gobierno, poder, orden, origen, vida, luz, esplendor, figura y manifestación), identidad que en lo múltiple brillaba con la luminosa presencia de la forma por encima de la materia, convocada por el armonioso conjunto de sus partes. Allí, de este modo, se entrelazaban todas las flores, hojas, macollas, zarcillos y corimbos de todas las hierbas que adornan los jardines de la tierra y del cielo, viola, cítiso, serpol, lirio, alheña, narciso, colocasia, acanto, malobatro, mirra y opobálsamos (1989: 56).

Aquí existe una licencia descriptiva, puesto que de todos los portales observados, no hay ninguno que corresponda al descrito; si bien se representan flores y plantas, éstas tienen un carácter más bien decorativo y de contexto, las podemos ver en las columnas o en los arcos superiores de los portales, y se repiten simétricamente a ambos lados, no son tan concentrados ni presentan tanta diversidad como en los diseños árabes. Aunque es tanta la información que a simple vista podría parecerlo.

\section{Octavo párrafo: descripción de los seres demoníacos}

(...) ¿Qué representaban y qué mensaje simbólico comunicaban aquellas tres parejas de leones entrelazados en forma de cruz dispuesta transversalmente, rampantes y arqueados, las zarpas posteriores afirmadas en el suelo y las anteriores apoyadas en el lomo del compañero, las melenas enmarañadas, los mechones que se retorcían como sierpes, las bocas abiertas, amenazadoras, rugientes, unidos al cuerpo mismo de la pilastra por una masa, o entrelazamiento denso, de zarcillos? (...) había, en los lados de la pilastra, dos figuras humanas, de una altura antinatural, correspondiente a la de la columna, que formaban pareja con otras dos, situadas simétricamente frente a cada una de ellas, en los pies rectos historiados por sus caras externas, donde estaban las jambas de las dos puertas de roble: cuatro figuras, por tanto, de ancianos venerables, cuya parafernalia me permitió reconocer que se trataba de Pedro y Pablo, de Jeremías e Isaías, también ellos vueltos como en un paso de danza, alzadas las largas manos 
huesudas con los dedos desplegados como alas, y como alas las barbas y cabelleras arrastradas por un viento profético, agitados los pliegues de sus larguísimas túnicas por unas piernas larguísimas que infundían vida a ondas y volutas, opuestos a los leones pero de la misma pétrea materia. (...) vi una hembra lujuriosa, desnuda y descarnada, roída por sapos inmundos, chupada por serpientes, que copulaba con un sátiro de vientre hinchado y piernas de grifo cubiertas de pelos erizados y una garganta obscena que vociferaba su propia condenación, y vi un avaro, rígido con la rigidez de la muerte, tendido en un lecho suntuosamente ornado de columnas, ya presa impotente de una cohorte de demonios, uno de los cuales le arrancaba de la boca agonizante el alma en forma de niñito (que, jay!, ya nunca nacería a la vida eterna), y vi a un orgulloso con un demonio trepado sobre sus hombros y hundiéndole las garras en los ojos, mientras dos golosos se desgarraban mutuamente en un repugnante cuerpo a cuerpo, y vi también otras criaturas, con cabeza de macho cabrío, melenas de león, fauces de pantera, presas en una selva de llamas cuyo ardiente soplo casi me quemaba (1989: 58).

Conocida es la iconografía medieval que ilustra sobre los seres satánicos, porque, como se sabe, el discurso religioso se sustentaba en el miedo al infierno para mantener control sobre el pecado. En la difusión del mensaje la imagen cumplió un papel fundamental, ilustrando todo tipo de tentaciones o castigos por los pecados realizados en vida. El medio generalmente usado fue el arte y la arquitectura, que, al estar dirigidos al pueblo analfabeto y común, conforma una estructura formal explícita. Su evidencia sólo se “oculta” a los ojos por medio de la redundancia, en el conjunto sobresaturado de personajes que están presentes para el que lo busca y se detiene en la contemplación.

Lo que resulta interesante en este párrafo es la impresión que de ella hace el monje, porque se refleja en su narración todo el impacto que debería causarle a un hombre piadoso de la época la observación de estos seres decadentes, cuya aparición se justifica en la obra por su contexto y finalidad didáctica. El orden de aparición de estos seres es alejado y en una ubicación inferior a la divinidad, pero es apropiado diferenciarlos de los seres mitológicos y fantásticos, híbridos de animales cuya aparición no siempre es la expresión de la maldad; en cambio, estos seres demoníacos siempre guardan relaciones antropomórficas suficientes para permitir cierto nivel de identificación con el observador y con ello provocar mayor temor:

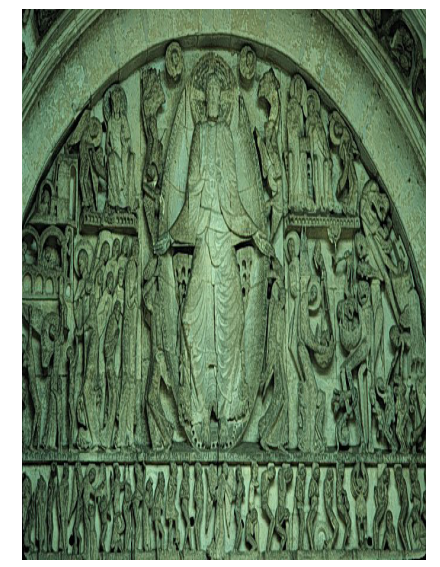

Ilustración No 3. Bajorrelieve del portal (lateral izquierdo) de la iglesia abacial de Moissac 


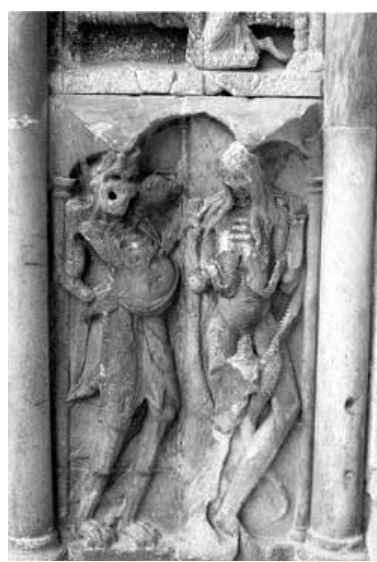

Ilustración $\mathrm{N}^{\mathrm{o}} 4$. Detalle (inferior derecho a la figura de Dios) del tímpano de la Catedral de St Lazare -Autun.

En el noveno párrafo, por su parte, se realiza la descripción y nominalización de los seres fabulosos:

Y alrededor de esas figuras, mezclados con ellas, por encima de ellas y a sus pies otros rostros y otros miembros, un hombre y una mujer que se cogían de los cabellos, dos serpientes que chupaban los ojos de un condenado, un hombre que sonreía con malignidad mientras sus manos arqueadas mantenían abiertas las fauces de una hidra, y todos los animales del bestiario de Satanás, reunidos en consistorio y rodeando, guardando, coronando el trono que se alzaba ante ellos, glorificándolo con su derrota: faunos, seres de doble sexo, animales con manos de seis dedos, sirenas, hipocentauros, gorgonas, arpías, íncubos, dracontópodos, minotauros, linces, leopardos, quimeras, cinóperos con morro de perro, que arrojaban llamas por la nariz, dentotiranos, policaudados, serpientes peludas, salamandras, cerastas, quelonios, culebras, bicéfalos con el lomo dentado, hienas, nutrias, cornejas, cocodrilos, hidropos con los cuernos recortados como sierras, ranas, grifos, monos, cinocéfalos, leucrocotas, mantícoras, buitres, parandrios, comadrejas, dragones, upupas, lechuzas, basíliscos, hipnales, présteros, espectáficos, escorpiones, saurios, cetáceos, esquítalas, anfisbenas, jáculos, dípsados, lagartos, rémoras, pólipos, morenas y tortugas. Portal, selva oscura, páramo de la exclusión sin esperanzas, donde todos los habitantes del infierno parecían haberse dado cita para anunciar la aparición, en medio del tímpano, del Sentado, cuyo rostro expresaba al mismo tiempo promesa y amenaza, ellos, los derrotados del Harmagedón, frente al que vendrá a separar para siempre a los vivos de los muertos. Desfalleciendo (casi) por aquella visión, sin saber ya si me hallaba en un sitio tranquilo o en el valle del juicio final, fui presa del terror y apenas pude contener el llanto, y creí oír (¿o acaso oí?) la voz, y vi las visiones que habían acompañado mi niñez de novicio, mis primeras lecturas de los libros sagrados y las noches de meditación en el coro de Melk, y en el delirio de mis sentidos debilísimos y debilitados oí una voz poderosa como de trompeta que decía "lo que vieres, escríbelo en un libro" (y es lo que ahora estoy haciendo), y vi siete lámparas de oro, y en medio de las lámparas uno semejante a hijo de hombre, (...). Y vi una puerta abierta en el cielo y El que en ella estaba sentado me pareció como de jaspe y sardónica, y un arco iris rodeaba el trono y del trono surgían relámpagos y truenos. Y el Sentado cogió una hoz afilada y gritó: “Arroja la hoz y siega, ha llegado la hora de la siega, porque está seca la mies de la tierra." Y El que estaba sentado arrojó su hoz sobre la tierra y la tierra quedó segada (1989: 58-59). 
Este párrafo es el que mejor representa la competencia en la iconografía medieval, se exagera y redunda en prácticamente todas las figuras mitológicas que se ven representadas en distintos portales y tímpanos del Medioevo. No existe ninguna con todas las descripciones que Adso narra, sin embargo, en la mayoría están presente parte de las imágenes e ilustraciones que describe. El discurso abruma con el excesivo detallismo y con la presencia de tantas figuras simbólicas. Las formas que se entrelazan en unidad, construyen un texto confuso, pero que resulta útil para transmitir el drama que en él se esconde. A la izquierda lo maligno, a la derecha el bien, hacia lo alto lo sublime, en los espacios inferiores lo pedestre, lo terrenal o bien, ya más abajo, lo maléfico, lo repugnante.

A esta altura, ya es casi imposible seguir la trama e imaginarse el frenesí imaginario de aquel portal, pero el esfuerzo tampoco resulta relevante, puesto que lo importante es precisamente provocar la confusión e impacto. Las imágenes verbales abruman al lector, el narratario debe comprender el texto para justificar el impacto del narrador, y la descripción del iconismo de parte del narrador, evoca las intenciones de motivar miedo y devoción, efecto que tenían la imágenes del Medioevo en sus devotos. La descripción de este párrafo no persigue la imagen mental como una recreación de lo observado, sino que espera la conmoción del lector, y lo consigue sin mostrar imágenes visuales. La abstracción de la palabra es lo que permite precisamente recrear un imaginario insólito, usa al iconismo sin caer en el ícono.

La iconicidad, en el capítulo analizado, es un instrumento para que el narrador exprese sus temores, contextualice historia y época; es un texto en donde la descripción de las imágenes encierra una profunda simbología que sólo puede comprender en totalidad el narratario competente a quien el narrador se dirige. El lector, como espectador, solo puede construir en parte el relato porque es capaz de reconstruir en su mente ligeros trazos de la imagen que se le narra, lo que no entiende simplemente lo adhiere, como quien enlaza una hebra distinta a un entretejido, y lo estructura como un conjunto de imágenes tan confuso y saturado como la observación directa de los mismos portales.

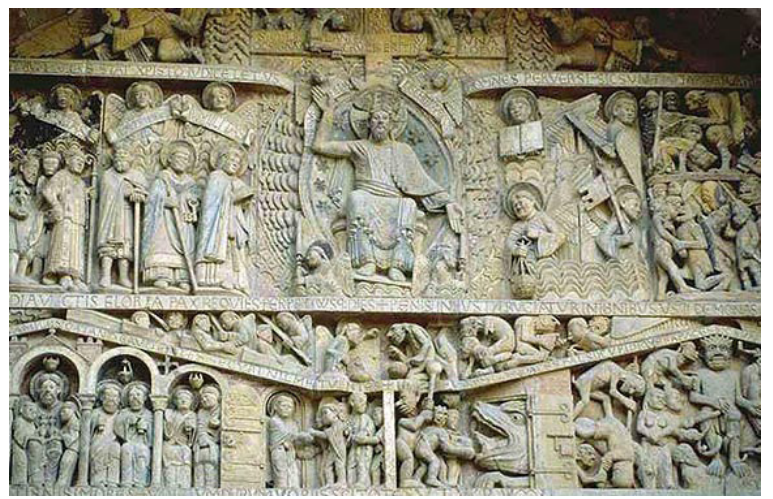

Ilustración No 5 . Tímpano de la Iglesia de la Abadía de Santa Fe de Conques

\section{CONCLUSIÓN}

El discurso verbal y el discurso icónico se encuentran en extremos opuestos de abstracción en la representación del mundo, sin embargo, ambos le permiten al 
ser humano explicarlo, cogerlo y aprehenderlo. Si bien las similitudes pueden ser lejanas o próximas en su referencia a lo topológico, dimensional, formal, cromático o cualquier otra variante existente dentro de las posibilidades de representación, todas ellas están sujetas a la competencia de la cultura que lo sustenta. El narrador, entonces, puede dirigirse a un narratario competente, que lo entienda, que comparta con él sus vivencias y que le permita narrar de la forma que a él le parece más adecuada, sus experiencias y emociones, condición que resulta válida tanto para el narrador que utiliza el lenguaje verbal como para el que usa el lenguaje visual.

Por otra parte, el lector real del texto decodificará a su manera el discurso, lo reconstruirá y recreará en su mente. En la mayoría de los casos hasta podrá reproducirlo en una imagen, pero, en el caso analizado, resulta interesante descubrir que si bien lo narrado es una descripción de una obra icónica, es prácticamente imposible reconstruir la imagen, en parte porque el resultado es una suma imaginada de retazos de imágenes conocidas y otras tantas desconocidas, que se encuentran en un conjunto insólito de situaciones prácticamente imposibles si no se conoce a fondo la Edad Media y su imaginario iconográfico. Es una descripción magistral que lleva al lector a creer en la existencia de una forma física que no existe y que no podría existir, pero que gracias a que está dirigida a un narratario que parece comprenderlo, da la ilusión de ofrecer huellas, da señales de su presencia y se hace creíble. Un mundo irreal, verosímil sobre la base de su existencia en la iconografía medieval, pero que al mismo tiempo se transforma en el discurso verbal en una serie de apreciaciones nuevamente imposibles, un abstracto dentro de otra abstracción, sostenida en la mente como una sucesión de eventos que se aparecen y se construyen con más o menos precisión en la medida que la experticia sobre el tema ayuda a imaginarlo.

El narrador, que no puede confiar en la competencia de cualquiera para explicar sus vivencias, se dirige a su narratario, cuya experticia no es puesta en duda, y es a partir de este diálogo entre seres que compartiendo códigos se entienden, es donde el lector, como un intruso que observa una conversación ajena, debe generar sus propias imágenes mentales y conclusiones. La iconicidad se presenta entonces como un elemento más, dentro de todo el conjunto de referentes culturales a los que el lector debe recurrir para entender el texto; trabajo que más complejo le resulta cuando lo que se comunica son fantasías, seres irreales, mitos o fábulas, cosas completamente ajenas a su cultura y tiempo. Resulta, entonces, que tener señales que posibiliten la ambientación en el entorno de la obra es una búsqueda crucial, porque al final lo relevante para estos simples mortales no es el detalle de lo descrito o nombrado -porque resulta casi imposible reconstruir, visualizar o precisar cada aspecto para formalizarlo en la mente como algún tipo de ícono-, sino la idea como convención cultural que subyace en cada palabra, signos de contenido impreciso o trazos de contenido, huellas con los que pueda entender débilmente lo que conformaba aquel mundo medieval.

\section{OBRAS CITADAS}

Bonsiepe, Gui. 1978. Teoría y Práctica del Diseño Industrial. Barcelona: Gustavo Gili. Carrasco, Hugo. 1982. "Introducción al estudio del narratario". Documentos lingüísticos y 
literarios 8: 15-22.

Chatman, Seymour. 1990. Historia y discurso, La estructura narrativa en la novela y en el cine. Barcelona: Taurus Humanidades.

Eco, Umberto. 1989. El nombre de la rosa. Apostillas a El nombre de la Rosa. Barcelona: Lumen.

Eco, Umberto. 1995. Tratado de Semiótica General. Barcelona: Lumen.

Foucault, Michel. 1968. Las palabras y las cosas, una arqueología de las ciencias. Buenos Aires: Siglo Veintiuno.

Kanizsa, Gaetano. 1986. Gramática de la visión. Percepción y pensamiento. Barcelona: Paidós. Morris, Charles. (1985). Fundamento de la Teoría de los signos. Barcelona: Paidós.

Perdomo, Alicia. 2002. “Un constructo, el narratario”. Context 6:8.

Prada, Renato. 1989. La narratología hoy. La Habana: Arte y Literatura. S.E.

Vilches, Lorenzo. 1990. La lectura de la imagen. Barcelona: Paidós.

Villafañe, Justo. 2000. Principios de teoría general de la imagen. Madrid: Pirámide

Wolf, K. y Khun, D. 1977. Forma y Simetría, una sistemática de los cuerpos simétricos. Buenos Aires: Universitaria.

\section{Ilustraciones:}

Ilustración N¹: St. María Magdalena de Tudela. Fuente: Mariluz (14 junio de junio de 2011). miradasdeloco.blogspot.com. Recuperado el 9 de julio de 2011. http://miradasdeloco. blogspot.com/2011/06/tudela-maria-magdalena.html\#axzz1RpuSykU1

Ilustración No2: Iglesia de San pedro de Moisacc. Fuente: Molano, J. A. (15 de junio de 2011). enzarzarte.blogspot.com. Recuperado el 9 de julio de 2011. http://enzarzarte.blogspot. com/2010/12/18-portada-de-san-pedro-de-moissac.html

Ilustración No3: Detalle (inferior derecho a la figura de Dios) del tímpano de la Catedral de St Lazare -Autun. Fuente: A digital archive of architecture Jeffery Howe, 1997 Boston College, St. Lazare, Autun, c. 1130-35. Recuperado el 9 de julio de 2011. http://www. bc.edu/bc_org/avp/cas/fnart/arch/romanesque_arch.html

Ilustración No4: Bajorrelieve del portal (lateral izquierdo) de la iglesia abacial de Moissac. Fuente: Eco, Umberto. 1989, Apostillas a El nombre de la rosa . Milán: Lumen, (pp: 15)

Ilustración Nº: Tímpano de la Iglesia de la Abadía de Santa Fe de Conques. Fuente: Salvador Estudiar arte en bachillerato, (2 febrero 2011). Recuperado el 9 de julio de 2011. http:// salvadorsg.blogspot.com/2011/02/timpano-moissac.html 